\title{
尿路結石症の発生原因に対する内分泌的検討
}

\section{第 V報カルチトニンの尿㧍よび血清電解質に対する影響について}

$\begin{array}{cccc} & \text { 郡 } & \text { 健 } & \text { 二 } \\ \text { 郎 } \\ & \text { 八 } & \text { 竹大学医学部泌尿器科 } & \text { 直 } \\ & \text { 栗 } & \text { 田 } & \text { 孝 }\end{array}$

\section{ENDOCRINOLOGICAL STUDIES ON PATHOGENESIS OF UROLITHIASIS}

V. Effect of Calcitonin in Urinary Electrolytes Excretion and Serum Electrolytes

Kenjiro Kohri, Sunao Yachiku and Takashi Kurita

Department of Urology, Kinki University School of Medicine, Sayama-cho, Minamikawachi-gun

Osaka-fu, Japan

(Director: Prof. T. Kurita)

In an earlier paper of this series, it is shown that calcitonin influences on the calcium metabolism of patients with urolithiasis, especially hypercalciuric patients. However little work has been done to evaluate effects of calcitonin on the urinary excretion of electrolytes and renal calcitonin metabolism.

Effect of calcitonin was studied in patients with primary hyperparathyroidism, hypercalcemic malignant tumors, and urinary calculi. We further investigated the calcitonin metabolism in intact and parathyroidectomized (PTX) rats.

Forty or eighty MRCunits of eel calcitonin which has the highest biological activity, was injected into the patients intramuscularly every morning. Every two-hour urine samples were collected after injection, and blood was collected three hours after injections.

The results were as follows:

1) Patients with malignant tumors had a serum calcitonin level significantly higher than those with hyperparathyroidism $(209.8 \pm 41.2 \mathrm{pg} / \mathrm{ml}, 63.2 \pm 38.8 \mathrm{pg} / \mathrm{ml}$ respectively, $\mathrm{p}<0.001)$. However, both parathyroid hormone and urinary cyclic AMP levels were significantly lower in the former than the latter. (parathyroid hormone $0.315 \pm 0.260 \mathrm{ng} / \mathrm{ml}, 6.10 \pm 7.63 \mathrm{ng} / \mathrm{ml}$ respectively, $\mathrm{p}<0.05$ ), (Urinary cyclic AMP 6.0 $\pm 5.0 \mu$ moles/g.cr, 12.4 $\pm 6.4 \mu$ moles/g.cr $\mathrm{p}<0.05)$.

2) Single injections of calcitonin induced a highly significant increase of the urinary excretion of calcium, phosphate, magnesium, and sodium after two hours. It returned to the previous level after eight hours. The preadministration serum calcium levels were directly proportional to the degrees of the decreases after administration.

3) The injection for several days caused a decrease of urinary calcium excretion in 8 of 11 cases, but minimal or no changes were observed in urinary phosphate excretion. There was no difference between malignant tumors and hyperparathyroidism.

4) Administration of eel calcitonin showed that there was minimal or no changes in serum calcitonin levels. Single injections of calcitonin caused moderate increases of parathyroid hormone in some cases, but no changes in the other cases.

5) Single injections of calcitonin resulted in a marked increase of urinary cyclic AMP excretion in patients with hyperparathyroidism, and there were moderate increase in those with malignant tumors. The cause of the increase remains unexplained, whether it is attributable to the calcitonin direct action or the parathyroid action followed by serum calcium reduction.

The following experiment was made to investigate this problem. Eel calcitonin was administered 
into intact and PTX rats, weighing about four hundred grams, intraperitoneally at a dose of $0.3 \mathrm{MR}$ Cunits/100 g body weight. Sample collection methods in this study was the same as that described in human beings. In this experiment slight to moderate increases in urinary cyclic AMP excretion was noted in intact rats as well as PTX rats. Based on this finding it is logical to believe that the increase is due to the calcitonin direct action, i.e, cyclic AMP may be the second messenger of calcitonin.

6) Injections of calcitonin for several days resulted in a marked reduction of urinary calcium excretion in four of five hypercalciuric patients (more than $200 \mathrm{mg} /$ day). But there was minimal or no changes in all normocalciuric patients. These results suggest that calcitonin is useful to investigate calcium metabolism in urolithiasis as well as to treat patients with urinary calculi.

要 旨: 第IV報に执いて，尿路結石症特に高 $\mathrm{Ca}$ 尿症の $\mathrm{Ca}$ 代謝にカルチトニン（以下 $\mathrm{CT}$ ）が関与している 可能性を報告した. しかし CT の腎に打ける作用や尿中電解質排泄作用に関する報告は少ない事から，高 $\mathrm{Ca}$ 血症を呈した悪性腫瘍患者と上皮小体機能立進症 (PHT), さらに尿路結石症に执いて CT 投与の影響を調べ た.また正常执よび上皮小体摘除 (PTX) ラットを用いCT の作用機序を究明した.

(1) 先ず始めに, 悪性腫瘍は PHT に比べ CT 值は有意に高く, 一方尿中 cAMP や上皮小体ホルモンは 著しく低く，この事は高 $\mathrm{Ca}$ 血症の鑑別診断に役立つるのであろう. (2) CT 投与にて血清 $\mathrm{Ca}$ や $\mathrm{Ca}$ 值は 投与前值に相関し低下がみられた。 (3) CT の 1 回投与にて尿中 $\mathrm{Ca}, \mathrm{Pi}, \mathrm{Mg}, \mathrm{Na}$ 排泄量及び尿量は各々その 変動パターンは多少異なるが，投与後約24時間目をピークに増加がみられた. (4) CT の長期投与では尿中 $\mathrm{Ca}$ は投与 $2 ， 3$ 日目から低下し，多くの症例で低下がみられた．その低下の程度は投与前值に相関してい た. (5) CT により上皮小体ホルモンや血清 CT 值の変化は僅かであつた. (6) CT にて尿中 cAMP が増加 した事から，PTX ラットを作成し CT を投与したところ，正常ラットとほぼ同様に尿中 cAMP の上昇をみ た.この事から cAMP の上昇は血清 $\mathrm{Ca}$ の低下による上皮小体機能の充進ではなく， CT が cAMP を介し 作用するためと推察された. (7) 尿路結石症では, Ca 排泄量が $200 \mathrm{mg} / \mathrm{day}$ 以上の群では著明に低下をみた。 $\mathrm{ECT}$ を用い結石症の $\mathrm{Ca}$ 代謝を詳細に知り得る可能性が考えられた。

尿路結石症の発生原因についてカルシウム（以下 $\mathrm{Ca}$ と略す) 代謝と内分泌, 特に上皮小体ホルモン（以下 PTH と略す) や，尿中 cyclic AMP (以下 cAMP と 略す) との関連性を中心に検討し，報告してきた ${ }^{1) ~ 3)}$. その際経口 $\mathrm{Ca}$ 負荷試験で, 高 $\mathrm{Ca}$ 尿症の結石患者に おいては，血清カルチトニン（以下 CT と略す）の值 が著しく上昇することを知つた ${ }^{3)}$ 。この事実から，PTH の他に CT もこの疾患の $\mathrm{Ca}$ 代謝と深く係わつている ものと考兄られた。

しかし CT の作用機序, 特腎に扩歪用や, 尿 中 $\mathrm{Ca}$ 排泄量への影響に関する報告は少ない，そこで 先ず始めに，CT の特に腎に和ける作用を知る目的で， 高 $\mathrm{Ca}$ 血症を呈した悪性腫瘍患者と, 上皮小体機能元 進症に対し，その $\mathrm{Ca}$ 動態を検討した。ささらに尿路 $\mathrm{Ca}$ 結石症に打ける CT の影響を調べるとともに, ラット に対する影響も合せ検討した。

\section{対象および方法}

(1) 高 $\mathrm{Ca}$ 血症症例飞対する CT 作用の検討 血清 $\mathrm{Ca}$ 值が $11.2 \mathrm{mg} / \mathrm{d} 1$ 以上の高 $\mathrm{Ca}$ 血症を呈した
悪性腫瘍患者 11 例（男性 8 例，女性 3 例，平均年齢 56.4 \pm 18.9 歳 $( \pm \mathrm{SD}))$ ， 原発性上皮小体機能穴進症 7 例 （男性 3 例，女性 4 例，平均年齢 $50.0 \pm 10.5$ 歳）, さらに 腎不全を原疾患とする続発性上皮小体機能六進症 2 例 （男性 2 例，年齢59扝よび50歳）を対象とした（Table 1).

CT 製剂は, 生物学的活性が $5,000 \mathrm{MRC}$ 単位 $/ \mathrm{mg}$ と 高く, かつ物理化学的にも安全とされる合成ウナギカル チトニン ([ $\left.\left.\mathrm{Asu}^{1.7}\right] \mathrm{ECT}\right)$ （以下 $\mathrm{ECT}$ と略す）を使用 した.

投与年に先立ち, ECT $0.04 \mathrm{MRC}$ 単位を含む生理食塩水 $0.05 \mathrm{ml}$ を前腕皮内に注入し, 過敏反応の有無を調べ た。

投与方法は，原則として 1 回 40MRC 単位を, 朝夕 2 回筋注した, 使用期間が 1 週間以上になり,かつ補液中の 症例には点滴内に投与し, 血清 $\mathrm{Ca}$ 值が高い症例 9 では, 1 日量 $240 \mathrm{MRC}$ 単位まで増量し㤂. ECT との併用薬剂 は症例 3，5，7，11飞拈いては，高 $\mathrm{Ca}$ 血症を呈する 以前から投与されていた抗癌剂を継続使用し，症例 9 で 
Table 1 検查対象のプロフィール（次面）

\begin{tabular}{|c|c|c|c|c|c|c|c|c|c|}
\hline Case & Sex & Age & Diagnosis & $\underset{(\mathrm{mg} / \mathrm{dl})}{\operatorname{Serum} \mathrm{Ca}^{*}}$ & $\underset{(\mathrm{mg} / \mathrm{dl})}{\operatorname{Serum}} \mathrm{Ca}^{*} *$ & $\underset{\text { (mg/day) }}{\text { Urinary } \mathrm{Ca}}$ & $\begin{array}{c}\text { Calcitonin } \\
(\mathrm{pg} / \mathrm{ml})\end{array}$ & $\begin{array}{l}\mathrm{PTH} \\
(\mathrm{ng} / \mathrm{ml})\end{array}$ & Others \\
\hline 1. Y.N. & $\widehat{\delta}$ & 68 & skin ca. & 11.5 & 6.64 & 324 & 188 & 0.4 & \\
\hline 2. T.H. & $\hat{o}$ & 70 & lung ca. & 12.5 & 6.12 & 480 & & & bone metastasis \\
\hline 3. K.A. & $\hat{o}$ & 68 & laryngeal ca. & 12.4 & 6.24 & 248 & & & bone metastasis \\
\hline 4. T.O. & $\hat{o}$ & 72 & laryngeal ca. & 11.3 & 5.18 & 581 & & & \\
\hline 5. K.S. & $\hat{o}$ & 70 & renal ca. & 11.4 & 5.88 & & 164 & 0.15 & \\
\hline 6. T.A. & 우 & 52 & renal ca. & 13.5 & 6.20 & 86 & & & bone metastasis \\
\hline 7. K. K. & 우 & 34 & renal ca. & 12.6 & 6.90 & 300 & 252 & 0.09 & bone $\&$ lung meta. \\
\hline 8. K. K. & $\hat{o}$ & 65 & ureter tumor & 13.9 & 6.90 & 384 & & & liver metastasis \\
\hline 9. M. K. & $\hat{o}$ & 13 & rhabdomyosarcoma & 16.0 & 8.10 & 1284 & 190 & 0.2 & fracture \\
\hline 10. K. N. & 우 & 64 & uterine ca. & 11.5 & 5.62 & 136 & & 0.8 & \\
\hline 11. M. T. & $\hat{\delta}$ & 44 & bladder tumor & 13.5 & 8.22 & 318 & 255 & 0.25 & \\
\hline 12. T.M. & 우 & 34 & $\mathrm{PHT}^{* *}$ & 11.2 & 5.68 & 216 & & 6.3 & \\
\hline 13. A.M. & 우 & 55 & PHT & 12.2 & 6.24 & 384 & 82.8 & 2.2 & osteoporosis \\
\hline 14. H. H. & $\hat{\delta}$ & 46 & PHT & 13.2 & 6.70 & 452 & & 4.9 & osteoporosis \\
\hline 15. H. S. & $\hat{\delta}$ & 54. & PHT & 11.5 & 5.36 & 210 & 110 & 22.5 & \\
\hline 16. M. T. & 우 & 64 & PHT & 13.3 & 5.92 & 121 & 6.8 & 5.9 & osteoporosis \\
\hline 17. H. K. & 우 & 57 & PHT & 12.0 & 6.36 & 264 & 68.1 & 0.6 & \\
\hline 18. M. I. & $\delta$ & 40 & PHT & 11.6 & 5.52 & 420 & 48.2 & 0.3 & \\
\hline 19. M. N. & o & 50 & SHT $* * *$ & 14.1 & 6.88 & & 484 & 8.7 & uremia \\
\hline 20. Y.Y. & $\hat{\delta}$ & 59 & SHT & 12.5 & 7.22 & & 848 & 0.66 & uremia \\
\hline
\end{tabular}

* Data are the maximum value, ** PHT : Primary Hyperparathyroidism *** SHT : Secondary Hyperparathyroidism

は悪性腫瘍と判明した ECT 使用の約10日目から抗癌剂 を使用し,さらに血清 $\mathrm{Ca}$ 值の低下が緩徐なためプレド ニン $20 \mathrm{mg} /$ day を併用した.

使用期間は上皮小体機能充進症においては全例共，上 皮小体腺腫または過形成摘除までの期間に限り使用し た. 悪性腫瘍症例は, 原則として退院又は死亡するまで の期間使用し, 症例 5 では腎腫瘍摘除後, 高 $\mathrm{Ca}$ 血症が 改善したため投与を中止した.

CT の作用効果の検討は, 長期と短期との両面からし た. 短期作用の検討は, 補液中の症例を除き全例, 起床 後絶领食と. し, 午前 8 時に ECT $80 \mathrm{MRC}$ 単位を筋注 し, 採尿は筋注前の 2 時間と, 筋注後 2 時間ごとに 8 時 間後までの計 5 検体を採集した。ささらに採血は午前 7 時 と, 血清 $\mathrm{Ca}$ 值が最も低下することが確かめられた筋注 3 時間後 (午前 11 時) にし, 後述する検査項目を測定し た。

長期作用の検討は, ECT を数日以上使用することが できた11症例に対し，1 日全尿の採尿と，採血をし，短
期と同様の検査をした。

(2) 上部尿路 $\mathrm{Ca}$ 結石症に対する ECT 作用の検討 赤外分光分析法により $\mathrm{Ca}$ を主成分とすることが判つ た尿路結 石症例 8 例（男性 5 例, 女性 3 例) に対 し, ECT $80 \mathrm{MRC}$ 単位を午前 7 時に筋注し, 尿中 Ca 排泄 量の変動抢よび血清 $\mathrm{Ca}$ 值を調べた。検査期間中の食餌 は, 上記の高 $\mathrm{Ca}$ 血症症例と同様, 1 日 $\mathrm{Ca}$ 含有量が 約 $700 \mathrm{mg}, \mathrm{P}$ 含有量が約 $1,000 \mathrm{mg}$ の入院食とし, 自由 领水とした。

(3) ラットに対する ECT 作用の検討

高 $\mathrm{Ca}$ 血症症例に ECT を投与した結果, 後に詳述す るごとく，尿中 $\mathrm{Ca}$ 排泄量の一過性の増加と平行し尿中 cAMP 排泄量も著明に増加することが判つた。 そこで この尿中 cAMP 排泄量増加の原因は, CT が作用する 時, PTH のように cAM P を second messenger として いるためなのか, それとる血清 $\mathrm{Ca}$ 值が低下する結果 PTH が動いたためなのかを調べる目的で, 次の実験を 行なつた。 
実験動物は，経時的に確実な採尿を得るように，平均 体重が約 400g の比較的大きい Wister 系雄ラットを用 いた. 動物は 2 群に分け，一方の群（6匹）に対し，吴 体䫓微鏡を用い6.3〜16倍の倍率にて，上皮小体のみを 摘出し，甲状腺は無傷に努めた。摘除後翌日に血清 $\mathrm{Ca}$ 值の低下を確認した後, 実験に供した。環境に馿らす 目的で，実験前日から日本クレア製 CT-10 ラット代謝 ケージにて飼育した．ECT 4MRC 単位を $1 \mathrm{ml}$ の生理食 塩水にて溶解し, 体重 $100 \mathrm{~g}$ 当り 0.3MRC 単位の ECT を腹腔内投与した。採尿は投与前後に 2 時間执きに 5 検 体を採取し，尿中 $\mathrm{Ca}$ 並びに尿中 cAMP 排泄量を測定 した.

(4) 検查項目とその測定方法

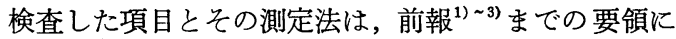
より, 血清 $\mathrm{Ca}$ 值, 血清イオン化カルシゥム值（以下血 清 $\mathrm{Ca}^{*}$ と略す), 血清燐酸值 (以下 $\mathrm{Pi}$ と略寸), 尿中 $\mathrm{Ca}, \mathrm{Pi}$ ，マグネシウム(以下 $\mathrm{Mg}$ と略す)，ナトリウム

（以下 $\mathrm{Na}$ と略す）の各々の排泄量を測定した. 内分泌 関係では血清 CT 值, 血清 PTH 值, 尿中 cAMP 排 泄量を測定した。

\section{結 果}

(1) 高 $\mathrm{Ca}$ 血症を呈する悪性腫瘍と上皮小体機能六進 症に括ける電解質值, PTH, CT 值の比較

ECT の効果を調べる前に, 悪性腫湯 と上皮小体機能 克進症に打ける各種検査值を比較検討した。

血清電解質は悪性腫瘍で血清 $\mathrm{Ca}$ 又は $\mathrm{Ca}^{*}$ 值が比較的 高い症例がみられるが，2 群間に有意差はなかつた．悪 性腫瘍が増覀するのに比例し血清 $\mathrm{Ca}$ 値が上昇した。

一一方血清 $\mathrm{Pi}$ 值は悪性腫瘍飞括将る平均が $3.0 \pm 0.3$ $\mathrm{mg} / \mathrm{dl}$ なのに対し，原発性上皮小体機能充進症では 2.0 $\pm 0.3 \mathrm{mg} / \mathrm{dl}$ と有意に低值であつた $(\mathrm{p}<0.001)$.

尿中電解質のうち $\mathrm{Ca}$ 排泄量は，悪性腫瘍では 458土 $266 \mathrm{mg} / \mathrm{g} . \mathrm{Cr}$ (平均士SD) と極めて多からたが，上皮小

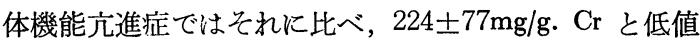
であつた。

尿中 $\mathrm{Pi}$ 排泄量も同様に悪性腫瘍では上皮小体機能立 進症に比べ有意に多かつた（各々 $1,020 \pm 297 \mathrm{mg} / \mathrm{g} . \mathrm{Cr}$, $412 \pm 126 \mathrm{mg} / \mathrm{g}$. Cr, $\mathrm{p}<0.001)$.

尿中 $\mathrm{Na}, \mathrm{Mg}$ ，尿酸排泄量は両群の間に差異はなく， 尿量もほぼ同量であつた。

両群の間に抢ける各種ホルモン值は特徵的な差異がみ られた。すなわち血清 CT 值は悪性腫瘍に和いて高値
であつたが（悪性腫瘍 5 例 $209.8 \pm 41.2 \mathrm{~g} / \mathrm{ml}$. 原発性 上皮小体機能充進症 5 例 $63.2 \pm 38.8 \mathrm{pg} / \mathrm{ml}, \mathrm{p}<0.001$ )， PTH P U-cAMP は上皮小体機能充進症で有意に高 值であつた。（PTH 值：悪性腫瘍 6 例 $0.315 \pm 0.260 \mathrm{ng}$ ， $\mathrm{ml}$ ，原発性上皮小体機能元進症 7 例 $6.10 \pm 7.63 \mathrm{ng} / \mathrm{ml}$, $\mathrm{p}<0.05$ ) (U-cAMP 值: 前者 10 例 $6.0 \pm 5.0 \mu \mathrm{moles} / \mathrm{g}$ $\mathrm{Cr}$, 後者 7 例 $12.4 \pm 6.4 \mu$ moles $/ \mathrm{g} \mathrm{Cr}, \mathrm{p}<0.05)$.

(2) 高 $\mathrm{Ca}$ 血症に扬ける ECT 投与による尿中電解 質排泄量の变動（短期結果）

先ず尿中 $\mathrm{Ca}$ 排泄量については，Fig. 1 のごとく $\mathrm{ECT}$ 投与後悪性腫瘍に颃いては，2時問後に増加し（p $<0.05)$ ，漸いに減少し 6 時閒に投与前值になつた。 上 皮小体機能六進症においても投与後上昇をみたが，その ピークは悪性腫瘍に比べ少し遅く，4時間後にみられ た。しかし症例によつてはその増加の程度は少なく，そ の上昇に有意差はなからた。

Fig. 1. カルチトニン投与後の尿中カルシウム排泄 量の経時的变化

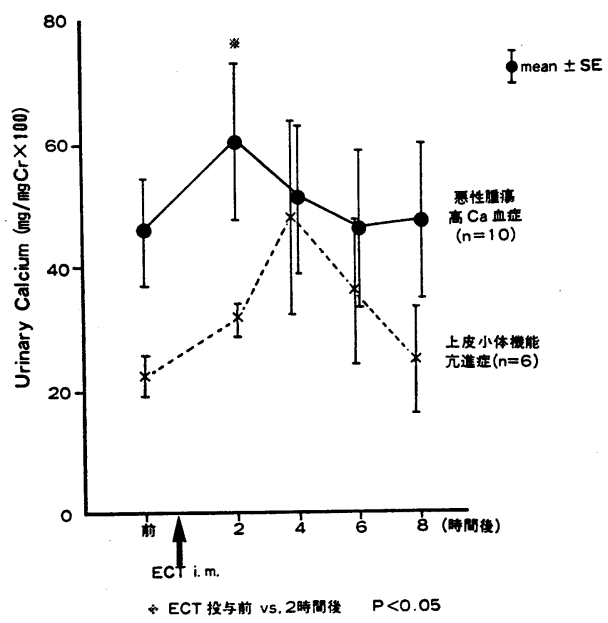

尿中 $\mathrm{Pi}$ 排泄量も $\mathrm{ECT}$ 投与により増加がみられた (Fig. 2). その増加の速度は尿中 $\mathrm{Ca}$ と同様, 悪性腫煌 では 2 時間後がピークなのに対し, 上皮小体機能充進症 では少し遅れ 4 時間後が最大值であつた。

尿中 $\mathrm{Mg}$ 排泄量の結果を Fig. 3 と示した。尿中 $\mathrm{Ca}$ や $\mathrm{Pi}$ 排泄量と同様, ECT 投与にて著明な増加がみら れたが，悪性腫瘍と上皮小体機能充進症の両群共に投与 後 8 時間目に执いても，投与前値まで低下をみなかつ た。

尿中 $\mathrm{Na}$ 排泄量の変動は, 今までの 3 種の電解質に 
Fig. 2. カルチトニン投与後の尿中リン排泄量の経 時的的化

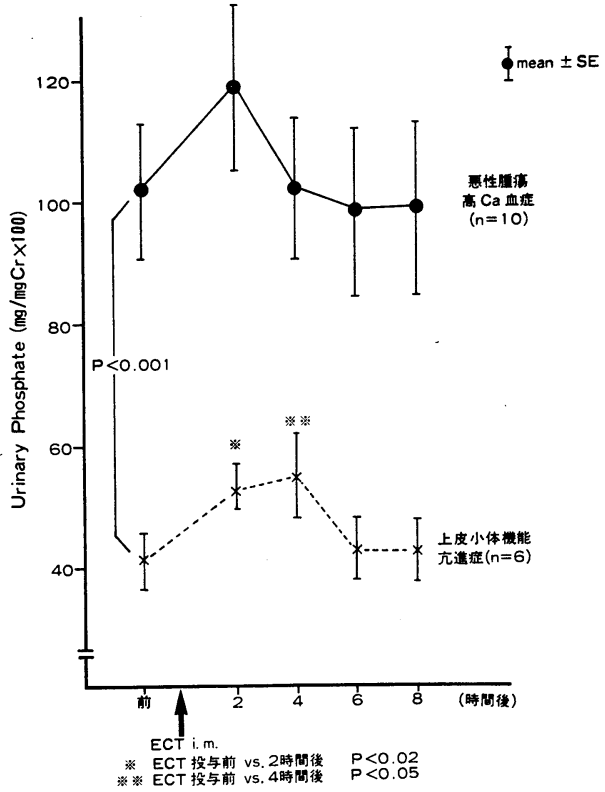

Fig. 3. カルチトニン投与による尿中マグネシウム 排泄量の経時的変化。

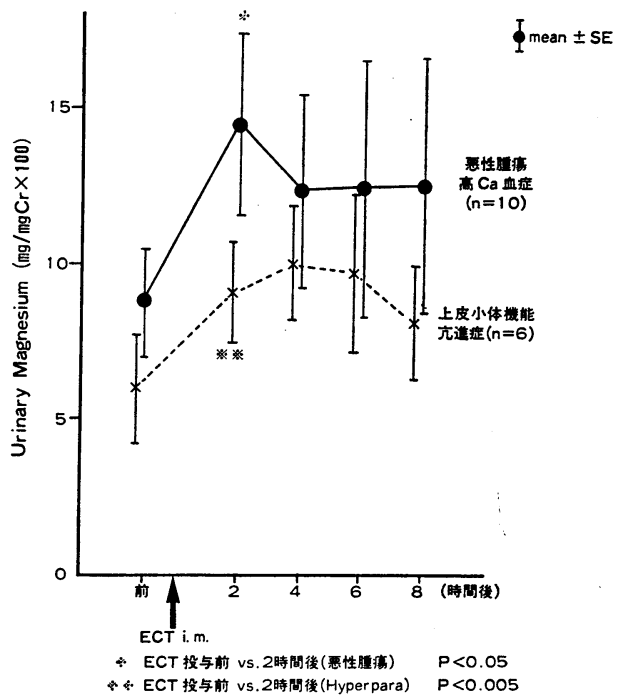

比べ，両群間での動きがほとんど羑異がないことが判つ た．その排泄量のピークは投与後 2 時間後で，他の電解 質と類似していた (Fig. 4).

尿量の変化を Fig. 5 と示した。そ動きは尿中 $\mathrm{Na}$ 排泄量と特に似たパターンを呈していた。即ち，ECT
Fig. 4. カルチトニン投与による尿中ナトリウの排 泄量の経時的変化

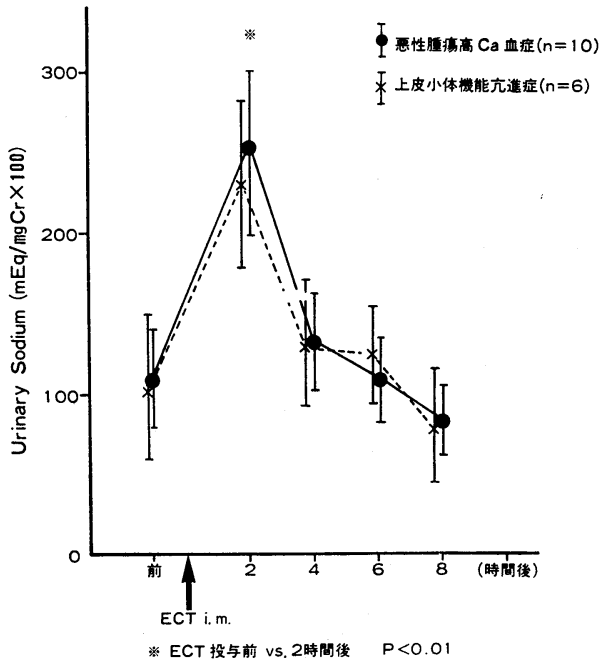

Fig. 5. カルトチニン投与による尿量の変化

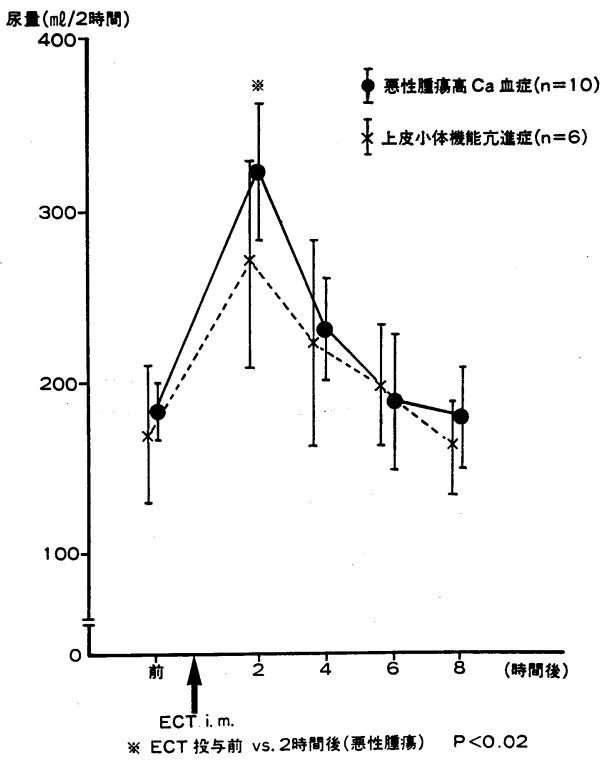

投与により両群共 2 時間後に最大値となり, 以後漸減し 投与後 6 時間後には投与前值まで戻ることが判つた．

(3) 高 $\mathrm{Ca}$ 血症に扣ける ECT 投与に上る尿中電解質 排泄量の変動 (長期結果)

ECT を 1 週間以上使用した11症例について 尿中電解 質の変化を調べた。その結果は Fig. 6 亿示すごとく, 尿中 $\mathrm{Ca}$ 排泄量は投与 2,3 日目から急激に減少する症 
Fig. 6. カルチトニン投与による尿中カルシウム排 泄のの経日的変化

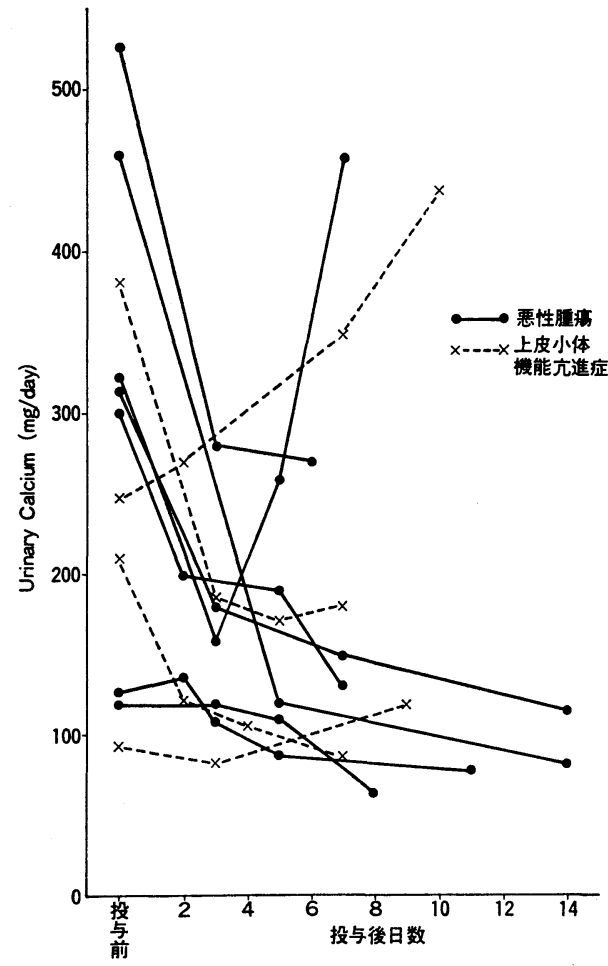

Fig. 7. カルチトニン投与による尿中リン排量量の 経日的变化

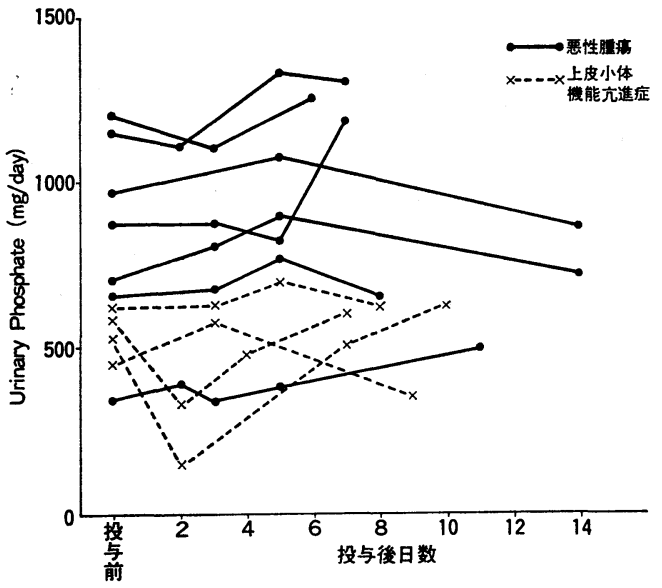

例が多く，1 週間目には投与前值に比べ，明かに低下し た症例が 8 例みられた。 その低下の割合は，投与前の尿 中 $\mathrm{Ca}$ 排泄量が多い症例では大きく，一方投与前値が正 常值では，その低下は少なかつた。また低下の程度は悪
Fig. 8. カルチトニン投与による血清カルシウム值 の低下（ $\Delta$ calcium）と投与前值との相関関係

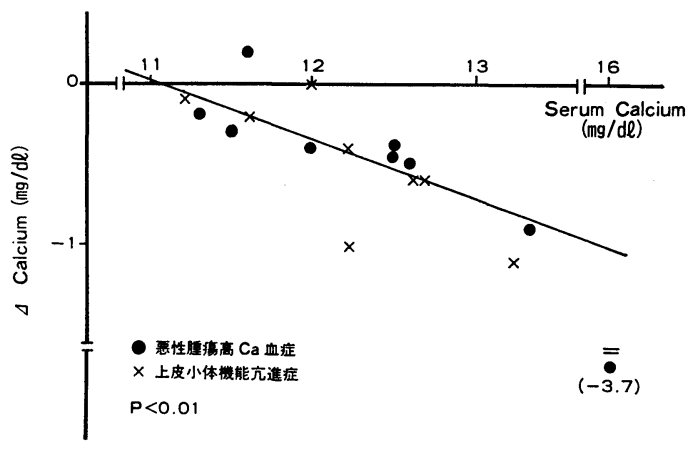

Table 2. カルチトニン投与による血清カルシウム 值の低下（ $\boldsymbol{- \Delta}$ Serum Calcium) と投与前值との 関係

\begin{tabular}{|c|c|c|c|}
\hline & \multicolumn{2}{|c|}{$-\Delta$ Serum Calcium } & \\
\hline & $<0.8 \mathrm{mg} / \mathrm{dl}$ & $>0.8 \mathrm{mg} / \mathrm{dl}$ & \\
\hline \multicolumn{4}{|c|}{ Serum Calcium } \\
\hline$<13 \mathrm{mg} / \mathrm{dl}$ & 1 & 3 & 4 \\
\hline \multirow[t]{2}{*}{$>13 \mathrm{mg} / \mathrm{dl}$} & 13 & 0 & 13 \\
\hline & 14 & 3 & 17 \\
\hline
\end{tabular}

性腫場と上皮小体機能症例との間飞特徵的な差異を見出 し得なかつた。

尿中 $\mathrm{Pi}$ 排泄量は有意な変化はみられなかつた。

(4) ECT 投与による血中電解質值の変動（短期結 果)

$\mathrm{ECT}$ 投与後 3 時間目の血清 $\mathrm{Ca}$ 值は，17例中15例に 低下をみ，1 例は不変，1 例はわずかだが上昇をみた。 その低下の度合は投与前の血清 $\mathrm{Ca}$ 值比例しているこ とが Fig. 8 から判つた。 そこで Table 2 のごとく，投 与前值が $13 \mathrm{mg} / \mathrm{dl}$ を境に 2 群に分け, 血清 $\mathrm{Ca}$ 值の低 下の程度をみると, $13 \mathrm{mg} / \mathrm{dl}$ 以上の 4 症例では $0.8 \mathrm{mg} /$ $\mathrm{dl}$ 以上低下した症例が 3 例なのに対し, $13 \mathrm{mg} / \mathrm{dl}$ 以下 の13症例では $0.8 \mathrm{mg} / \mathrm{dl}$ 以上低下した症例はみられなか つた. 悪性腫瘍と上皮小体機能六進症との間で，血清 $\mathrm{Ca}$ 值の低下の程度には差異はなかつた。

血清 $\mathrm{Ca}^{\#}$ 值についてもほぼ同様の結果を得た。すな わち投与前值が高い症例ではとの低下は著明にみられ， 一方低い症例では血清 $\mathrm{Ca}^{*}$ の低下効果は少なかつた (Fig. 9). 
Fig. 9. カルチシニン投与による血清イオン化カル シウムの低下と投与前值との相関関係

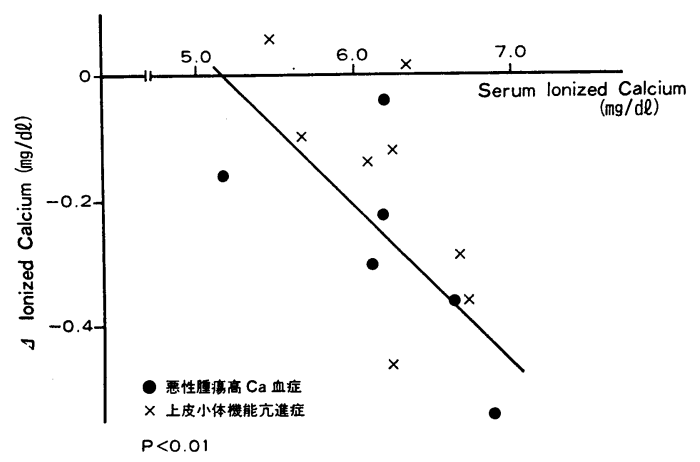

Fig. 10. カルチトニン投与による血清カルシウム 值の経日的変化

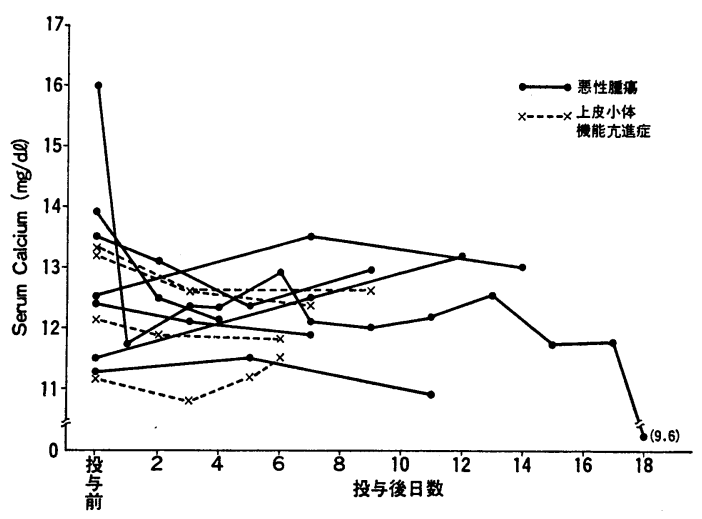

血清 $\mathrm{Pi}$ 值の動きは, 悪性腫瘍並びに上皮小体機能え 進症共に一定の動きはみられなかつた。

(5) ECT 投与に上る血清電解質の変動 (長期結果)

ECT 投与飞よる血清 $\mathrm{Ca}$ 值の 経日的変化を Fig. 10 に示した. 経時的変化でもみられたごとく，投与前值が 高い症例ではその低下作用も大きい傾向がみられた。し かし悪性腫瘍でその増悪化と共に血清 $\mathrm{Ca}$ 值の上昇もあ り，必ずしも低下する症例ばかりではなかつた。一方 Fig. 10 に示した投与前值が $16 \mathrm{mg} / \mathrm{dl}$ の症例では, $\mathrm{CT}$ の投与並びに輸液により, 血清 $\mathrm{Ca}$ 值の急激な低下 をみたが，再び上昇傾向がみられ，又悪性腫瘍の診断が 得られたため, 抗癌剤を使用し再び急激な低下をみ，正 常値になつた。

血清 $\mathrm{Pi}$ 值は経時的変化の時同様，変化はほとんどみ られなかつた。

（6）上部尿路結石症に招ける ECT 投与による尿中 $\mathrm{Ca}$ 值の変動
尿路結石症に和ける ECT 投与による尿中 $\mathrm{Ca}$ 排泄 量の経日的変化を Fig. 11 亿示した. 投与前の 1 日尿中 $\mathrm{Ca}$ 排泄量の $200 \mathrm{mg} /$ 日を境に結石症を大別したところ， Ca 排泄量が多い群では 5 例中 4 例に排泄量の低下がみ

Fig. 11. 尿路結石症におけるカルチトニン投与に よる尿中カルシウム排泄量の経日的変化

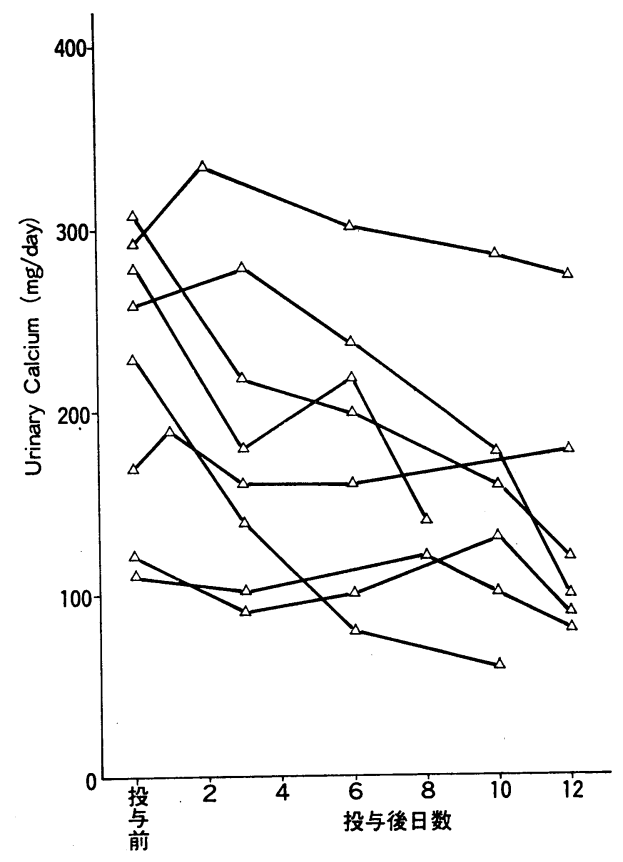

Fig. 12. カルチトニン投与による尿中 cyclic AMP 排泄量の経時的変化

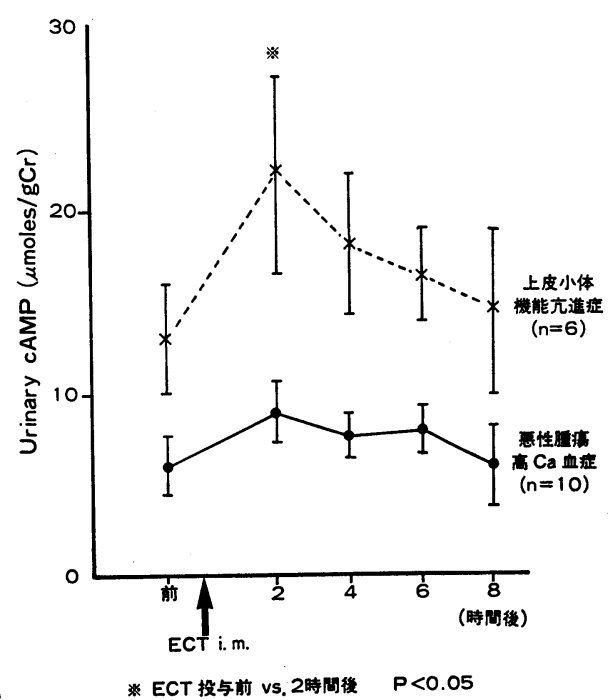


られ，投与前值の平均 $\pm \mathrm{SD}$ の $275.3 \pm 31.4 \mathrm{mg} /$ day と 投与最終日の值の $141.2 \pm 86.7 \mathrm{mg} /$ day との間には有意 差がみられた $(\mathrm{p}<0.02)$. しかし $\mathrm{Ca}$ 排泄量の少ない群 では，排泄量にほとんど変化はみられなかつた。

(7) ECT 投与による各種内分泌機能の変動

$\mathrm{ECT}$ 投与による尿中 $\mathrm{cAMP}$ 排泄量の経時的変化を Fig. 12 亿示した. 投与前の尿中 cAMP 值はすでに第 2 報で詳述したと同様, 上皮小体機能充進症では極めて 高值であつた。しかし悪性腫瘍に拈ける值は，光進症に 比べ有意に低值であつたが，すでに報告した正常人や尿 路結石症例に比べると高い值の症例がみられた。

上皮小体機能充進症に打惊 $\mathrm{ECT}$ 投与後 2 時間目の 值は，投与前値の約 2 倍近くにも上昇し $(\mathrm{p}<0.05)$, そ の後潮减し 8 時間後には投与前值近くまで低下した。一 方悪性腫瘍では，ECT 投与により尿中 cAMP 排泄量 は增加するものの, その上昇率は克進症に比へ低く, 症 例によつては変化はなかつた。

PTH 值の変化は Table 3 に示すごとく, 上皮小体機 能六進に怙いては，ECT 投与 3 時間後には上昇する症 例もみられた。しかし全体的にはその上昇率は僅かであ つた。

Table 3. カルチトニン投与による上皮小体ホルモ ン (PTH) と血清カルチトニンの変化

\begin{tabular}{|c|c|c|c|c|}
\hline & \multicolumn{2}{|c|}{ PTH (ng/ml) } & \multicolumn{2}{|c|}{$\begin{array}{l}\text { Calcitonin } \\
(\mathrm{pg} / \mathrm{ml})\end{array}$} \\
\hline & pre * & post* & pre & post \\
\hline \multirow{2}{*}{$\begin{array}{c}\text { malignant tumor } \\
(n=5) \\
p \text {-value }\end{array}$} & $\begin{array}{l}0.248^{* *} \\
\pm 0.142 \\
\end{array}$ & $\begin{array}{l}0.302 \\
\pm 0.234\end{array}$ & $\begin{array}{l}203.4 \\
\pm 42.4\end{array}$ & $\begin{array}{l}190.8 \\
\pm 62.6\end{array}$ \\
\hline & \multicolumn{2}{|c|}{ n. s. } & \multicolumn{2}{|c|}{ n. s. } \\
\hline \multirow{2}{*}{$\begin{array}{l}\text { primary } \\
\text { hyperparathyroidism } \\
(\mathrm{n}=7) \\
\mathrm{p} \text {-value }\end{array}$} & $\begin{array}{l}4.28 \\
\pm 2.84\end{array}$ & $\begin{array}{l}5.77 \\
\pm 3.24\end{array}$ & $\begin{array}{l}61.7 \\
\pm 32.4\end{array}$ & $\begin{array}{l}58.4 \\
\pm 42.7\end{array}$ \\
\hline & \multicolumn{2}{|c|}{ n. s. } & \multicolumn{2}{|c|}{$(n=5)$ n.s. } \\
\hline
\end{tabular}

* pre : preadministration, post : postadministration

** mean $\pm \mathrm{SD}$

血清 CT 值の変化も Table 3 飞示した. 投与前値は 悪性腫瘍と上皮小体機能立進症との間に著しく異なつた が，ECT 投与後の変化は一定なものがなかつた。

(8) ラットに拈ける ECT 投与による尿中 $\mathrm{Ca}$ 和上び cAMP 排泄量の変化

$\mathrm{ECT}$ の腹腔内投与による尿中および血清 $\mathrm{Ca}$ 值の变 化を Fig. 13，14 に示した. 上皮小体無傷ラット（以 下正常ラットと略す)の ECT 投与前の血清 $\mathrm{Ca}$ 值は $10.3 \pm 0.3 \mathrm{mg} / \mathrm{dl}$ と人と注ぼ同值であつたが, 上皮小体 摘除ラット (以下 PTX ラットと略す) は $5.4 \pm 0.4 \mathrm{mg} /$
Fig. 13. 正常および上皮小体摘除ラットにおける カルチトニン投与による血清カルシウム值の変化

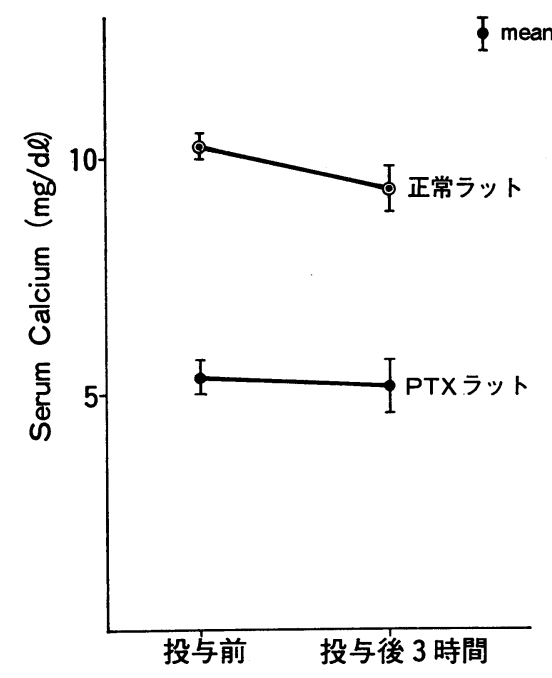

Fig. 14. 正常および上皮小体摘除ラットにおける カルチトニン投与による尿中カルシウム排泄量の 経時的変化

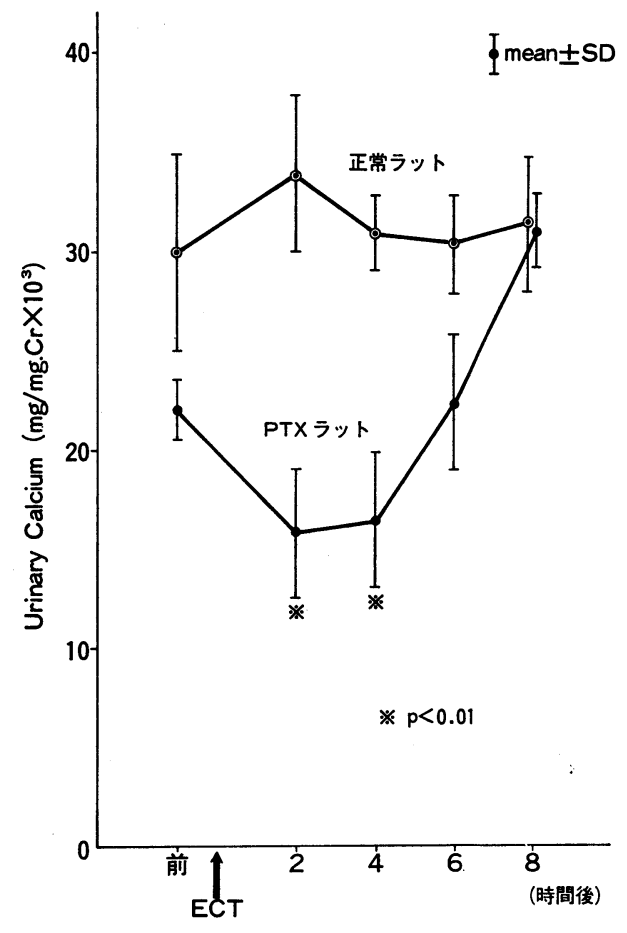

dl と極めて低值であつた. ECT 投与による血清 $\mathrm{Ca}$ 值 の低下は，正常ラットでは人と同様の低下をみたが， PTX ラットに拈ける低下は僅かであつた (Fig. 13). 
Fig. 15. 正常および上皮小体摘除ラットに拈ける カルチトニン投与による尿中 cyclic AMP 排泄 量の経時的変化

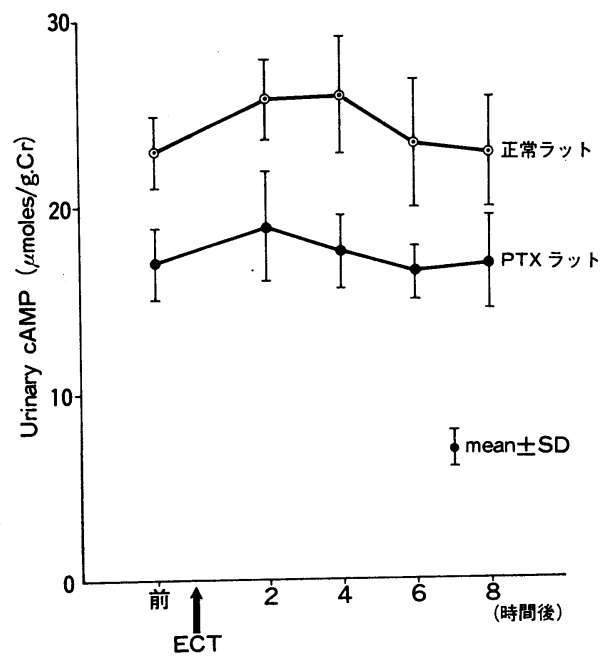

Fig. 16. ウナギカルチトニンの化学構造. ヒト， サケカルチトニンの化学構造. ヒト, サケカルチ トニン等では一部のアミノ酸が異なっている。

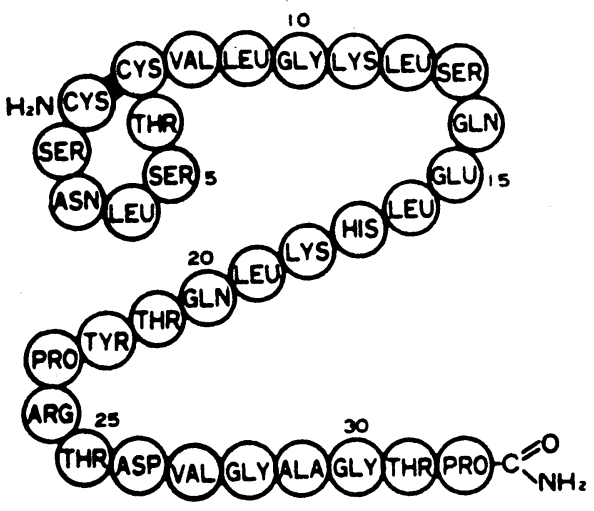

尿中 $\mathrm{Ca}$ 排泄量については, ECT 投与前值は PTX ラットで僅かに低いが有意差はなかつた（Fig. 14). $\mathrm{ECT}$ 投与後の尿中 $\mathrm{Ca}$ 排泄量の变化は, 前述の人之は 異なり，正常ラットでは増加の傾向がみられたが有意差 はなく、また PTX ラットでは逆に有意な低下がみら れた。

尿中 cAMP 排泄量の変化を Fig. 15 に示した.ラッ トに括ける尿中 cAMP 值は正常ラットは勿論, PTX ラットに打いても人に比べ極めて高值であつた．PTX ラットと正常ラットとの間には有意な差異はなかつた。 ECT 投与により正常ラットは勿論, PTX ラットでも尿
中 cAMP 排泄量は増加傾向に有することが判つた.

\section{考案}

CT は Copp $^{4)}$ とより命名され, Munson, Hirsch ら ${ }^{5)}$ がその血清 $\mathrm{Ca}$ 值低下作用を詳細像べた32個のアミ， 酸からなる単鎖のポリペプタイドである (Fig. 16). 現 在までにアミノ酸配例が決定されている CT は, ヒト CT をはじめウシ，ブタ，サケなど8つある。この内今 回使用したウナギ CT は，ブタ CT やサヶ CT に比べ 血中で不活性化され難く, また哺乳類の CT の生物活 性は 50 200MRC 単位/mg であるが，ウナギ CT の活 性は5,000MRC 単位 $/ \mathrm{mg}$ と高い特徵がある ${ }^{6)}$.この天然 ウナギ CT のアミノ基末端から 1 番目と 7 番目のシス チンを $\alpha$-L-アミノスベリン酸に置換した合成ウナギ CT (東洋醸造製) を使用し, 種々の検討をした。

(1) 高 $\mathrm{Ca}$ 血症症例の鑑別

高 $\mathrm{Ca}$ 血症を是する疾患性種々知られている7 。 その 内泌尿器科領域に打いては, 上皮小体機能充進症と悪性 腫瘍との鑑別に苦慮することがある. 自験例でも症例 9 では, 腫瘍の存在が長い間わからず上皮小体の試験摘除 までしている.

しかし今回の検討の結果明かになつたことは，この症 例13を含め大半の悪性腫瘍症例では上皮小体機能立進症 飞比べ, 血清 PTH 值が低く正常值を呈し，一方血清 CT 值が極めて高值であつた。この事実は将来，両者を 鑑別する有力な方法になり得ると思われた。

症例10では血清 PHT 值が高いが, 子宮癌の Stage IV で放射線治療中のため腫瘍内の PTH 濃度は測定し得 ていないが, PTH 様物質生産腫瘍の可能性を考えられ $ろ^{8)}$.

続発性上皮小体機能六進症では血清 CT 值が最も高値 であつた，その理由は CT は腎において不活性化され たり，腎から排泄されることから ${ }^{910)}$ ，腎機能低下によ る結果と考学る。また Munson ${ }^{11)}$ の述べるごとく, PTH 分泌が充進しているため，その反応として CT 分泌が 多いことも考えられる.

(2) ECT. による尿中電解質の変動について

$\mathrm{CT}$ により尿中 $\mathrm{Ca}$ 排泄量は増加するとの説 ${ }^{12) 13}{ }^{143}$ と，減少するとの説 ${ }^{15) 16)}$ の相反する意見がある．この違 いは今回の結果から，CT の投与回数や投与対象の種類 により異なることが判つた. 即ち人では CT の 1 回投 与では排泄は促進されるが，反復又は連続投与では減少 の傾向をみた。 またラットにおいては 1 回投与でる増加 は余りみられなかつた。さらに諸家の報告を検討したと 
ころ, CT 製剤の種類や投与量によつても多少異なるの ではないかと思われた。

1 回投与により尿中 $\mathrm{Ca}$ 量が増加したことは後述の血 清 $\mathrm{Ca}$ 值を低下させるという CT 本来の目的が腎臓に おいて働くためと思われる。

一方長期使用時の排泄量減少の機序は, 血清 $\mathrm{Ca}$ 值 の低下による糸球体 $\mathrm{Ca}$ 万過量の減少が原因と考学る. しかし血清 $\mathrm{Ca}$ 值が低下しない症例でも，尿中 $\mathrm{Ca}$ 排 泄量が減少した機序は CT の骨吸収抑制により血液内 の $\mathrm{Ca}$ プールが減るためと思われる.

CT の尿中 $\mathrm{Pi}$ 排泄量に対する作用は, CT が発見さ れた当初からリン酸利尿が有ることが報告されてお $り^{17)}$ ，その後の報告も一致したものである ${ }^{14) 16) 18)}$. CT のこの作用機序は, 血清 $\mathrm{Ca}$ 值の低下に伴なう PTH 分 泌充進による二次的なものではなく，CT の腎に対する 直接作用として知られている ${ }^{13) 18) 199}$.

尿中 $\mathrm{Mg}$ 排泄量の变化は, 自験例では増加をみたが S $\phi$ rensen $~^{16)}$ や Rasmussen $~^{20)}$ は減少したと報告して いる. この違いの原因は, 尿中 $\mathrm{Ca}$ と同様に投与対象の 種属（彼らはラットによる実験結果）による差である可 能性が有り. 今後の検討課題である.

尿中 $\mathrm{Na}$ 排泄量の変化は, 尿中 $\mathrm{Ca}$ や $\mathrm{Mg}$ と異なり, 投与対象種属や投与量の差とは無関係に, 一様に増加す るものと思われる。一般に尿中 $\mathrm{Na}$ 排泄之尿中 $\mathrm{Ca}$ 排 泄とは, 増加や減少の両者共同じ方向に作用するとされ ているが21)，上の結果から， CT の尿中 $\mathrm{Na} と \mathrm{Ca}$ との 作用には必ずしも一致しないこととが推察される.

$\mathrm{Na}$ 利尿に伴ない自験例のごとく尿量が増えたが，CT の作用は一般の利尿剤と類似している点が多いとされ

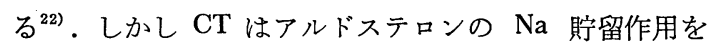
防げないことや，フロセマイドでは副腎摘除ラットでも 利尿効果があるが CT ではみられないこと ${ }^{23)}$ から作用機 序を異にしていると思われる。

（3） ECT による血清電解質の変動について

血清 $\mathrm{Ca}$ 值に対する ECT の低下作用は, 血清 $\mathrm{Ca}$ 值 が高いほど大きく, 尿路結石症などの正常域では低下は 僅かであつた。 また PTX ラットでは血清 Ca 值は不 変に近かつたことや，老秢ラットに比べ幼若ラットでは

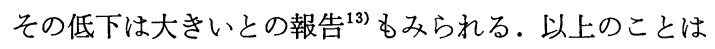
CT の効果は骨代謝が充進している時に, 強く発揮され るとの報告と一致する.

(4) ECT による内分泌機能の変化について

$\mathrm{ECT}$ 投与により尿中 cAMP が著しく上昇することを
経験したことから，これが CT の直接作用であるか， 血清 $\mathrm{Ca}$ 值低下による $\mathrm{PTH}$ 分泌を促す結果であるのか を知るため PTX ラットにて調べたところ，PTX ラッ トでは尿中 $\mathrm{Ca}$ 排泄量が低下し, 血清 $\mathrm{Ca}$ 值が不変で あるにかかわらず，尿中 cAMP が增加傾向を示したこ とから，CT が cAMPを Second messenger として作 用しているものと推察された。

$\mathrm{CT}$ とAMP との関係を論じた報告はいくつか散見 でき，CT により cAMP が上昇するとの意見が多

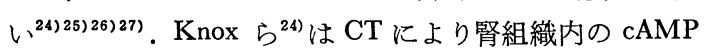
やアデニールサイクレースも上昇するとし, Queener $ら^{25)}$ は PTH は腎皮質でのみ cAMP が増えるが，CTは 腎䯣質に打いても上昇することを認め，また Chabardes $ら^{27)}$ もアデニールサイクレースの面から PTH と CT との作用部位の異なることを示唆している.

CT も PTH 同様, cAMPを second messenger とし ていることが推察されたが，CT による cAMP の上昇 はPTH に比べ著しく少ないとされている ${ }^{26)}$.また CT による cAMP の上昇は大量投与で始めてみられ，少 量では変化なかつたとの報告も有ることから, 尿中 cAMP の多くは, 従来から云われているごとく ${ }^{28) 29330}$, PTH がその供給源になつていると考える.

(5) 尿路結石症に対する ECT の効果について

結石症に ECT を使用したところ，1日の Ca 排泄 量が $200 \mathrm{mg}$ 以上と多い症例では 5 例中 4 例が尿中 $\mathrm{Ca}$ 排泄量の著明な低下をみたが，排泄量が少ない症例では 変化はなかつた。この事実は, 前報3)で尿路結石症の高 $\mathrm{Ca}$ 尿症と正常 $\mathrm{Ca}$ 尿症との間には, カルチトニンに関 する $\mathrm{Ca}$ 代謝が異なる結果を裏付け得たものと云える.

しかし $\mathrm{Ca}$ 排泄量の多い症例でも, ECT に反応しな い症例がみられた。この事がすぐに高 $\mathrm{Ca}$ 尿症の $\mathrm{Ca}$ 代 謝解明に結びつきはしないが，今後 ECT を使用するこ とにより, 結石症の $\mathrm{Ca}$ 代謝を究明する方法を得られる 可能性も推察された.

ECT を現段階で尿路結石症に実用化させる可能性は, 自験例の結果が連日の筋肉注射投与であつたで, すぐに は難しいが，高 $\mathrm{Ca}$ 尿が尿路結石の発生原因の 1 つと考 えられている現在, 今後週 1 度程度で効果を得られる方 法を検討していきたい.

\section{結 論}

高 $\mathrm{Ca}$ 血症を呈した悪性腫瘍 11 例と原発性上皮小体機 能六進症 7 例括よび正常と上皮小体摘除ラットにウサギ カルチトニン (ECT) を使用し, 尿中電解質を中心とす 
る $\mathrm{Ca}$ 代謝への影響を調べた。さらに尿路結石症の $\mathrm{Ca}$ 代謝の究明と，その治療目的にカルチトニンを使用でき ないかを検討した。

1. 悪性腫瘍患者は上皮小体機能克進症症例に比へ， 血清 CT 值は有意汇高く $(\mathrm{p}<0.001)$ ，上皮小体ホルモ ン $(\mathrm{PTH})$ や尿中 cyclic AMP 排泄量は低值を示した $(\mathrm{p}<0.05)$.この事は高 $\mathrm{Ca}$ 血症の鑑別診断に有効な一 助と考觉られた。

また前者に比べ，血清 $\mathrm{Pi}$ 值が低く $(\mathrm{p}<0.001)$, 尿 中 $\mathrm{Ca}$ や尿中 $\mathrm{Pi}$ 排泄量は多かつた $(\mathrm{p}<0.001)$. 血清 $\mathrm{Ca}$ 値や $\mathrm{Ca}^{*}$ 值, 尿中 $\mathrm{Na}, \mathrm{Mg}$, 尿酸排泄量に差異はな かつた.

1. ECT を80MRC units を 1 回投与すると, 悪性腫 瘍と元進症の両群共, 尿中 $\mathrm{Ca}, \mathrm{Pi}, \mathrm{Mg}, \mathrm{Na}$ 排泄量は 全て投与後 2 時間後をピークに増加をみ，約 8 時間後に 元の值に戻つた. 但尿中 $\mathrm{Mg}$ の低下は 8 時間後でも投 与前值まで戻らなかつた。

1. 血清 $\mathrm{Ca}$ 及び $\mathrm{Ca}^{*}$ 值は投与前值が大きい程その 低下は顕著で，その間に相関関係を認めた。血清 $\mathrm{Pi}$ 值 は変化がなかつた。

1. ECT を長期投与すると，尿中 $\mathrm{Ca}$ 排泄量は，11 例中 8 例で 2,3 日目から急減し始め, 1 週目に投与前 值近くになつた。 その低下の程度は投与前值が大きい程 著しかつた，尿中 $\mathrm{Pi}$ 排泄量は有意な変化はみられなか つた.

1. ECT により尿中 cyclic AMP は2 時間後に有意 な上昇をみ $(\mathrm{p}<0.05)$, その後漸減し 8 時間後には前值 まで低下した。この上昇の原因が CT が作用した結果 の直接的なるのか, 血清 $\mathrm{Ca}$ 值の低下による上皮小体 機能の充進による 2 次的なるのかを調べる目的で，ラッ トに ECTを投与したところ，正常ラットは勿論上皮 小体摘除ラットに执いても尿中 cyclic AMP の上昇が みられた。この事から CT は cyclic AMP をsecond messenger として作用している可能性が推察された。

1. ECT により血清 PTH 值は一部の症例に打いて 上昇をみたが，他の症例では変化はなく，全体的にも有 意差はなからた。また血清 $\mathrm{CT}$ 值変化に特徴的なもの はなかつた。

1. 尿路結石症では尿中 $\mathrm{Ca}$ 排泄量が $200 \mathrm{mg} /$ day 以 上と多い症例では 5 例中 4 例に投与後約 1 週間後に有意 に低下をみた $(\mathrm{p}<0.02)$. しかし排泄量の低い症例では 変化はなからた。この事は結石症の中に CT に関する $\mathrm{Ca}$ 代謝が異なる可能性が示唆された。
また ECT を用い結石症の $\mathrm{Ca}$ 代謝を調べたり，治 療の目的に実用化される可能性が考兄られた。

\section{文献}

1) 郡健二郎, 八竹 直, 栗田 孝: 尿路結石症の 発生原因に対する内分泌学的検討。第 II 報，原 発性上皮小体機能六進症における cyclic AMP の動態について。 日泌尿会誌，71，626-637， 1980.

2）郡健二郎：尿路結石症の発生原因に対する内分 泌学的検討。第報カルシウム結石症における カルシウム代謝と上皮小体機能について，日泌 尿会誌, 71，1980.

3）郡健二郎：尿路結石症の発生原因に対する内分 泌学的検討。第IV報カルシウム制限および負荷 試験による高カルシウム尿症における病態生理 の研究。日泌尿会誌, 71, 1980.

4) Copp, D.H., Cameron, E.C., Cheney, B.A., Davidson, A.G.F. and Henze, K.G.: Evidence for calcitonin a new hormone from the parathyroid that lowers blood calcium. Endocrinology, 70, 638-649, 1962.

5) Hirsch, P.F., Gauthier, G.F. and Munson, P.L.: Thyroid hypocalcemic principle and recurrent laryngeal nerve injury as factors affecting the response to parathyroidectomy in rats. Endocrinology, 73, 244-252, 1963.

6）折茂 肇，大畑雅洋，藤田拓男，吉川政己，阿 部仁之助, 渡辺 晋, 小谷 勝, 東 禎三: Ultimobranchial Calitonin 関する研究 (1), ウナギカルチトニンの発見。医学のあゆみ, 79, 477-478, 1971.

7) Juan, D.: Differential diagnosis of hypercalcemia. A mechanistic approach. Postgraduate Medicine, 66, 72-81, 1979.

8) Besarab, A. and Caro, J.F.: Mechanisms of hypercalcemia in malignancy. Cancer,, 41 2276-2285, 1978.

9) DeLuise, M., Martin, T.J. and Melick, R.A.: Tissue distribution of calcitonin in the rat. Comparison with parathyroid hormone. J. Endocr., 48, 173-179, 1970.

10) Sraer, J., Ardaillou, R. and Covette, S.: Increased binding of calcitonin to renal receptors in parathyroidectomized rats. Endocrinology, 96, 632-637, 1974.

11) Munson, P.L.: Thyrocalcitonin: Physiological importance and significance in renal failure. Am. J. Med. Sci., 262, 310-319, 1971.

12) 藤本守, 松村裕: 腎飞打りる $\mathrm{Ca}, \mathrm{P}$ の輸 送機序。 日本臨床，36，3304-3313，1978.

13）尾形悦郎，木村 哲：カルチトニンの腎作用. 腎とカルシゥム，第 1 版，p. 44-p. 79，医歯 薬出版, 東京, 1973 。 
14) Ardaillou, R., Fillastre, J.P., Milhaud, G., Rousselet, F., Delaunay, F. and Richet, G.: Renal excretion of phosphate, calcium and sodium during and after a prolonged thyrocalcitonin infusion in man. Proceeding Soci. Experime. Medi., 131, 56-60, 1969.

15）森井浩世, 岡本輝夫, 松下義樹, 越智宏暢, 石 田俊武, 三島泰彦, 塚本雄壮 : カルチトニンの 臨床的応用, 腎とカルシウム, 第 1 版. p. 80p. 101, 医出版, 東京, 1973.

16) S $\phi$ rense, C and Hindberg, I.: The acute and prolonged effect of porcine calcitonin on urine electrolyte excretion in intact and parathyroidectomized rats. Acta Endocrinologica, 70, 295-307, 1972.

17) Kenny, A.D. and Heiskell, C.A.: Effect of crude thyrocalcitonin on calcium and phosphorus metabolism in rats. Proc. Soc. Exp. Biol. Med., 120, 269-271, 1965.

18) Roninson, C.J., Martin, T.J. and MacIntyre, I.: Phosphaturic effect of thyrocalcitonin. Lancet, II, 83-84, 1966.

19) Milhaud, G. and Moukhtar, M.S.: Antagonistic and synergistic actions of thyrocalcitonin and parathyroid hormone on the levels of calcium and phosphate in the rat. Nature, 211, 1186-1187, 1966.

20) Rasmussen, H., Anast, C. and Arnaud, C.: Thyrocalcitonin EGTA, and urinary electrolyte. J. Clin. Invest., 46, 746-752, 1967.

21) Wills, M.R., Gill, J.R. and Barter, F.C. Jr.: The interrelationships on calcium and sodium excretions. Clin. Sci., 37, 621-630, 1969.

22) Parfitt, A.M.: The acute effect of mersalyl, chlorothiazide and mannitol on the renal excretion of calcium and other ions in man. Clin. Sci., 36, 267-282, 1972.

23) Aldred, J.P., Kleszynski, R.R., Stubbs, R.K. and Bastian, J.W.: Requirement of the adrenal for certain urine electrolyte effects of salmon colcitonin in rats. Proc. Soc. Exp. Biol. Med., 137, 1145-1151, 1971.

24) Knox, F.G., Preiss, J., Kim, J.K. and Dousa, T.P.: Mechanism of resistance to the phosphaturic effect of the parathyroid hormone in the hamster. J. Clin. Invest., 59, 675-683, 1977.

25) Queener, S.F. and Bell, N.H.: Calcitonin: A general survey. Metabolism, 24, 555-567, 1975.

26) Murad, F., Brewer, H.B. Jr. and Vaughan, M.: Effect of thyrocalcitonin on adenosine $3^{\prime}: 5^{\prime}$-cyclic phosphate formation by rat kidney and bone. Proc. Natl. Acad. Sci. USA, 65, 446-453, 1970.

27) Chabardés, D., Imbert-Teboul, M., Montégut, M., Clique, A. and Morel, F.: Distribution of calcitonin-sensitive adenylate cyclase activity along the rabbit kidney tubule. Proc. Natl. Acad. Sci. USA, 73, 3608-3612, 1976.

28) Chase, L.R. and Aurbach, G.D.: Parathyroid function and the renal excretion of $3^{\prime} 5^{\prime}$ adenylic acid. Proc. N.A.S., 58, 518-525, 1967.

29) Jost, J.P. and Rickenberg, H.V.: Cyclic Amp. Ann. Rev. Biochem., 40, 741-774, 1971.

30) Hardman, J.G., Robison, G.A. and Sutherland, E.W.: Cyclic nucleotides. Ann. Rev. Physiol., 33, 311-336, 1971.

（1980年 7 月 21 日 特別掲載） 